\title{
Pleural Effusion, Ascites, and Thrombocytopenia Associated with Acute Hepatitis A Virus Infection
}

\author{
Akut Hepatit A ilişkili Plevral Efüzyon, Asit ve Trombositopeni
}

\author{
İskender EKINCI'1 is , Yusuf KAYAR² iD \\ 'Department of Internal Medicine, Bezmialem Vakif University School of Medicine, İstanbul, Turkey \\ ${ }^{2}$ Department of Internal Medicine, Division of Gastroenterology, Bezmialem Vakif University School of Medicine, İstanbul, Turkey
}

\section{Dear Editor,}

Although acute hepatitis A virus (HAV) infection is usually self-limiting, it may be rarely accompanied by extrahepatic manifestations such as evanescent rash, leukocytoclastic vasculitis, arthritis, glomerulonephritis, pleural effusion, ascites, cryoglobulinemia, autoimmune hemolytic anemia, and thrombocytopenia (1-3). The development of ascites may be associated with the transient elevation of pressure in portal and hepatic veins. It is caused by increase in hepatic sinusoidal pressure and decrease in oncotic pressure because of hypoalbuminemia. Pleural effusion is likely related to inflammation of the liver, immune complex mediated or transport of ascites to pleura through the lymphatics (4). Thrombocytopenia is associated with the accumulation of immune complex on the platelet surface (5). To our knowledge, this is the first case in which all these three extrahepatic manifestations were observed in a single adult patient.

A 35-year-old man admitted with a five-day history of nausea, vomiting, and jaundice. He had no comorbidities and no medical history. On physical examination the patient was icteric with normal vital signs, and liver was palpable 3 $\mathrm{cm}$ below the costal margin. Laboratory examination yielded the following; hemoglobin: $16.4 \mathrm{~g} / \mathrm{dL}$, white blood cell count: $10.3 \times 10^{3} / \mu \mathrm{L}$, platelet count: $255 \times 10^{3} / \mu \mathrm{L}$, ALT: $1970 \mathrm{U} / \mathrm{L}$, AST: $1104 \mathrm{U} / \mathrm{L}$, ALP: $102 \mathrm{U} / \mathrm{L}, \mathrm{GGT}: 218 \mathrm{U} / \mathrm{L}$, total bilirubin: $9.4 \mathrm{mg} / \mathrm{dL}$, direct bilirubin: $6.9 \mathrm{mg} / \mathrm{dl}$, total protein: $6 \mathrm{~g} / \mathrm{dL}$, albumin: $3 \mathrm{~g} / \mathrm{dL}$, prothrombin time: 17.5 s, and INR: 1.29. HAV immunoglobulin (Ig) M and HAV IgG were positive, whereas all viral markers for hepatitis B, C, D, and E were negative. Serological analyses for herpes simplex virus, Epstein-Barr Virus, cytomegalovirus, and parvovirus were negative. The right costophrenic angle was observed blunted in the chest X-ray. Abdominal ultrasonography and contrast-enhanced abdominal computerized tomography (CT) revealed ascites in perihepatic, perisplenic, and subdiaphragmatic areas, and acute hepatitis without biliary tract pathologies. In contrast-enhanced thorax CT, a right-sided pleural effusion with no parenchymal infiltration was observed. Supportive treatment was initiated. Until the $3 \mathrm{rd}$ day of admission, the platelet count decreased progressively to $60 \times 10^{3} / \mu \mathrm{L}$, and it was verified by peripheral blood smear examination. Laboratory analyses, including direct and indirect Coombs tests, antinuclear antibodies, liver-kidney microsomal antibody, mitochondrial antibody, smooth muscle antibody, anti-soluble liver antigen, anticardiolipin IgM-IgG, anti-phospholipid IgM-IgG, protein electrophoresis, serum and 24-hour-urine copper, serum ceruloplasmin, and fecal alpha-1 antitrypsin did not reveal any abnormalities. Thrombocyte count gradually returned to normal values by the $11^{\text {th }}$ day without treatment. Radiological examinations on the $11^{\text {th }}$ day of admission showed regression of pleural effusion and ascites. Level of liver function tests decreased to completely normal values by the $18^{\text {th }}$ day of admission.

Although the complications related to acute HAV infection is usually self-limiting and resolves spontaneously, as in the present case, it should be borne in mind that it may progress to a life-threatening condition in some cases.

Cite this article as: Ekinci I, Kayar Y. Pleural Effusion, Ascites, and Thrombocytopenia Associated with Acute Hepatitis A Virus Infection. Bezmialem Science 2018; 6(3): 236-7. 
Informed Consent: Written informed consent was obtained from patient who participated in this study.

Peer-review: Externally peer-reviewed.

Author Contributions: Concept - İ.E., Y.K.; Design - İ.E., Y.K.; Supervision - İ.E., Y.K.; Data Collection and/or Processing - İ.E.; Analysis and/or Interpretation - İ.E., Y.K.; Literature Search - İ.E.; Writing Manuscript - İ.E., Y.K.; Critical Review - Y.K.

Conflict of Interest: The authors have no conflicts of interest to declare.

Financial Disclosure: The authors declared that this study has received no financial support.

Hasta Onamı: Yazılı hasta onamı bu çalışmaya katılan hastadan alınmıştır.

Hakem Değerlendirmesi: Dış bağımsız.

Yazar Katkıları: Fikir - İ.E., Y.K.; Tasarım - İ.E., Y.K.; Denetleme - İ.E., Y.K.; Veri Toplanması ve/veya İşlemesi - İ.E.; Analiz ve/veya
Yorum - İ.E., Y.K.; Literatür Taraması - İ.E.; Yazıyı Yazan - İ.E., Y.K.; Eleştirel İnceleme - Y.K.

Çıkar Çatışması: Yazarlar çıkar çatışması bildirmemişlerdir.

Finansal Destek: Yazarlar bu çalışma için finansal destek almadıklarını beyan etmişlerdir.

\section{References}

1. Taylor RM, Davern T, Munoz S, Han SH, McGuire B, Larson AM, et al. Fulminant hepatitis A virus infection in the United States: Incidence, prognosis, and outcomes. Hepatology 2006; 44: 1589-97. [CrossRef]

2. Ko YS, Yoo KD, Hyun YS, Chung HR, Park SY, Kim SM, et al. A case of pleural effusion associated with acute hepatitis A. Korean J Gastroenterol 2010; 55: 198-202. [CrossRef]

3. Erdem E, Urgancı N, Ceylan Y, Kara N, Ozcelik G, Gulec SG. Hepatitis a with pleural effusion, ascites and acalculous cholecystitis. Iran J Pediatr 2010; 20: 479-82.

4. Yolcu CT, Uyan AP, Baysoy G. Ascites and Pleural Effusion: Rare Complications of Hepatitis A Infection in Children. Turk Thorac J 2009; 10: 98-100.

5. Shenoy R, Nair S, Kamath N. Thrombocytopenia in hepatitis A--an atypical presentation. J Trop Pediatr 2004; 50: 241-2. [CrossRef] 